\title{
The influence of tillage and fertilizer on the flux and source of nitrous oxide with reference to atmospheric variation using laser spectroscopy
}

\author{
Peggy H. Ostrom (D) Samuel DeCamp • Hasand Gandhi • Joshua Haslun • \\ Nathaniel E. Ostrom
}

Received: 10 June 2020/Accepted: 27 November 2020/Published online: 4 January 2021

(C) The Author(s) 2021

\begin{abstract}
Nitrous oxide $\left(\mathrm{N}_{2} \mathrm{O}\right)$ is the third most important long-lived greenhouse gas and agriculture is the largest source of $\mathrm{N}_{2} \mathrm{O}$ emissions. Curbing $\mathrm{N}_{2} \mathrm{O}$ emissions requires understanding influences on the flux and sources of $\mathrm{N}_{2} \mathrm{O}$. We measured flux and evaluated microbial sources of $\mathrm{N}_{2} \mathrm{O}$ using site preference $\left(S_{\mathrm{P}}\right.$; the intramolecular distribution of ${ }^{15} \mathrm{~N}$ in $\mathrm{N}_{2} \mathrm{O}$ ) in flux chambers from a grassland tilling and agricultural fertilization experiments and atmosphere. We identified values greater than that of the average atmosphere to reflect nitrification and/or fungal denitrification and those lower than atmosphere as increased denitrification. Our spectroscopic approach was based on an extensive calibration with 18 standards that yielded $S_{\mathrm{P}}$ accuracy and reproducibility of $0.7 \%$ and $1.0 \%$, respectively, without preconcentration. Chamber samples from the tilling experiment taken $\sim$ monthly over a year showed a wide range in $\mathrm{N}_{2} \mathrm{O}$ flux $\left(0-1.9 \mathrm{~g} \mathrm{~N}_{2} \mathrm{O}-\mathrm{N} \mathrm{ha}^{-1} \mathrm{~d}^{-1}\right)$ and $S_{\mathrm{P}}(-1.8$ to
\end{abstract}

Responsible Editor: Melany Fisk

Supplementary Information The online version of this article (https://doi.org/10.1007/s10533-020-00742-y) contains supplementary material, which is available to authorized users.

P. H. Ostrom $(\bowtie) \cdot$ S. DeCamp · H. Gandhi ·

J. Haslun · N. E. Ostrom

Department of Integrative Biology and DOE Great Lakes

Bioenergy Research Center, Michigan State University,

East Lansing, MI 48824, USA

e-mail: ostrom@msu.edu
$25.1 \%$ ). Flux and $S_{\mathrm{P}}$ were not influenced by tilling but responded to sampling date. Large fluxes occurred in October and May in no-till when soils were warm and moist and during a spring thaw, an event likely representing release of $\mathrm{N}_{2} \mathrm{O}$ accumulated under snow cover. These high fluxes could not be ascribed to a single microbial process as $S_{\mathrm{P}}$ differed among chambers. However, the year-long $S_{\mathrm{P}}$ and flux data for notill showed a slight direct relationship suggesting that nitrification increased with flux. The comparative data in till showed an inverse relationship indicating that high flux events are driven by denitrification. Corn (Zea mays) showed high fluxes and $S_{\mathrm{P}}$ values indicative of nitrification $\sim 4 \mathrm{wk}$ after fertilization with subsequent declines in $S_{\mathrm{P}}$ indicating denitrification. Although there was no effect of fertilizer treatment on flux or $S_{\mathrm{P}}$ in switchgrass (Panicum virgatum), high fluxes occurred $\sim 1$ month after fertilization. In both treatments, $S_{\mathrm{P}}$ was indicative of denitrification in many instances, but evidence of nitrification/fungal denitrification also prevailed. At $2 \mathrm{~m}$ atmospheric $\mathrm{N}_{2} \mathrm{O} S_{\mathrm{P}}$ had a range of $31.1 \%$ and $14.6 \%$ in the grassland tilling and agricultural fertilization experiments, respectively. These data suggest the influence of soil microbial processes on atmospheric $\mathrm{N}_{2} \mathrm{O}$ and argue against the use of the global average atmospheric $S_{\mathrm{P}}$ in isotopic modeling approaches.

Keywords Nitrous oxide $\cdot$ Site preference $\cdot$ Laser spectroscopy $\cdot$ Grassland $\cdot$ Agriculture $\cdot$ Atmosphere 


\section{Introduction}

The greenhouse gas, nitrous oxide $\left(\mathrm{N}_{2} \mathrm{O}\right)$, is an important contributor to stratospheric ozone depletion (Ravishankara 2009) and has a 100-year global warming potential that is approximately 300 times that of $\mathrm{CO}_{2}$ (Intergovernmental Panel on Climate Change 2014). Given its increase from 270 to 330 ppbv since preindustrial times and long atmospheric lifetime ( $\sim 114$ years) $\mathrm{N}_{2} \mathrm{O}$ is viewed as an important driver of climate change (Gelfand and Robertson 2015; Park et al. 2012; Prather et al. 2015; Prinn et al. 2000; Prinn 2013). Nearly $40 \%$ of annual $\mathrm{N}_{2} \mathrm{O}$ emissions are anthropogenic and if post-harvest activities and land-use conversion are discounted, agriculture accounts for $\sim 84 \%$ of these emissions (Gelfand and Robertson 2015; Ussiri and Lal 2013). Elevated $\mathrm{N}_{2} \mathrm{O}$ emissions in agriculture are a consequence of alteration of soil microbial activity, fertilization, cultivation of $\mathrm{N}$ fixing plants and various management practices (McGill et al. 2018; McSwiney and Robertson 2005; Shcherbak et al. 2014). Thus, mitigation strategies require information on the influence of different agricultural practices on the sources and flux of $\mathrm{N}_{2} \mathrm{O}$. Microbial nitrification and denitrification are the primary sources of $\mathrm{N}_{2} \mathrm{O}$ (Ostrom and Ostrom 2012). While nitrification is dependent on oxygen and ammonium availability, denitrification requires low oxygen, a carbon substrate and nitrate. Thus, understanding the response of $\mathrm{N}_{2} \mathrm{O}$ production pathways to events such as tilling and fertilization that influence soil aerobicity, carbon availability and inorganic nitrogen affords the potential for developing guidelines to manage agricultural $\mathrm{N}_{2} \mathrm{O}$ emissions (Ostrom and Ostrom 2012). In this study we investigate the influence of tilling and fertilization, on the sources and flux of $\mathrm{N}_{2} \mathrm{O}$.

The relative importance of different microbial pathways to $\mathrm{N}_{2} \mathrm{O}$ production can be investigated with isotope analyses (Ostrom and Ostrom 2012). Site preference $\left(S_{\mathrm{P}}\right)$, the difference in ${ }^{15} \mathrm{~N}$ abundance between the central $\mathrm{N}\left(\delta^{15} \mathrm{~N}^{\alpha}\right)$ and terminal $\mathrm{N}\left(\delta^{15} \mathrm{~N}^{\beta}\right)$ atoms of $\mathrm{N}_{2} \mathrm{O}$, has gained attention as an indicator of the microbial origin of $\mathrm{N}_{2} \mathrm{O}$ (Baggs 2008; Bol et al. 2003; Park et al. 2011; Sutka et al. 2006; Yoshida and Toyoda 2000). The large difference in $S_{\mathrm{P}}$ of $\mathrm{N}_{2} \mathrm{O}$ produced from nitrification (hydroxylamine oxidation) or fungal denitrification and denitrification ( $\sim 39 \%$ ) paired with the observations that $S_{\mathrm{P}}$ is constant during $\mathrm{N}_{2} \mathrm{O}$ production and independent of the isotopic composition of the nitrogen substrates for $\mathrm{N}_{2} \mathrm{O}$ production prompted the use of $S_{\mathrm{P}}$ for $\mathrm{N}_{2} \mathrm{O}$ source apportionment (Sutka et al. 2006; Toyoda et al. 2005). Note here that $\mathrm{N}_{2} \mathrm{O}$ production by nitrifiers via nitrite reduction and bacterial denitrifiers are collectively described as "denitrification" because the genes involved, and $S_{\mathrm{P}}$ values associated with the reduction of nitrite or nitrate by nitrifiers and bacterial denitrifiers are similar (Sutka et al. 2006).

Adding an understanding of the origins of $\mathrm{N}_{2} \mathrm{O}$ to flux measurements is a powerful and necessary tool for mitigation and establishing $\mathrm{N}_{2} \mathrm{O}$ budgets. However, isotope approaches are not without uncertainties that confound their use for quantifying the relative contributions of nitrification/fungal denitrification and denitrification to $\mathrm{N}_{2} \mathrm{O}$ production. $\mathrm{N}_{2} \mathrm{O}$ reduction serves to increase $S_{\mathrm{P}}$, essentially overemphasizing the importance of production from nitrification/fungal denitrification. However, its influence on $S_{\mathrm{P}}$ appears to be small and is related to the amount of $\mathrm{N}_{2} \mathrm{O}$ reduced (Ostrom et al. 2007; Opdyke et al. 2009). Using a simultaneous production/reduction model, Ostrom and Ostrom (2017) estimated the influence of $\mathrm{N}_{2} \mathrm{O}$ reduction on flux chamber samples taken in southern Michigan. The amount of $\mathrm{N}_{2} \mathrm{O}$ reduced was no greater than $30 \%$ which equated to a shift in $S_{\mathrm{P}}$ of $2.5 \%$. Further for nearly half of the samples the amount of reduction was $10 \%$ or less which is equivalent to a change in $S_{\mathrm{P}}$ of $0.8 \%$.

Even in the absence of $\mathrm{N}_{2} \mathrm{O}$ reduction, methods to quantify sources of $\mathrm{N}_{2} \mathrm{O}$ are confronted by a host of other uncertainties. $S_{\mathrm{P}}$ values reported for the microbial endmembers vary by several per mil (Toyoda et al. 2017). And, although rarely reported, a close inspection of the literature shows that the $S_{\mathrm{P}}$ of atmospheric $\mathrm{N}_{2} \mathrm{O}$ is not always constant, varying by $2.5 \%$ or more within a year (Toyoda et al. 2013; Yu et al. 2019). Such variation raises concerns for the use of mass balance models, such as isotope mapping, to estimate the isotope composition of soil derived $\mathrm{N}_{2} \mathrm{O}$ from, for example, flux chambers. These models assume that at closing $\mathrm{N}_{2} \mathrm{O}$ in flux chamber has two sources, the atmospheric source and microbially derived $\mathrm{N}_{2} \mathrm{O}$. They also assign the global average atmospheric isotope value to the atmospheric source. They do not account for the possibility that $\mathrm{N}_{2} \mathrm{O}$ in the initial chamber atmosphere could be a mixture of $\mathrm{N}_{2} \mathrm{O}$ from the atmosphere and microbial production. Such a 
mixture would be isotopically distinct from the global average. Isotope mapping methods are further compromised by the observation that the magnitude in fractionation in $\delta^{15} \mathrm{~N}$ of $\mathrm{N}_{2} \mathrm{O}$ during production and reduction are not constant and there can be exchange with water during $\mathrm{N}_{2} \mathrm{O}$ production that can influence $\delta^{18} \mathrm{O}$ (Lewicka-Szczebak et al. 2017; Ostrom and Ostrom 2017; Toyoda et al. 2017; Haslun et al. 2018).

We took a conservative qualitative approach to interpret flux chamber head space $S_{\mathrm{P}}$. Given our previous estimates of the influence of $\mathrm{N}_{2} \mathrm{O}$ reduction on $S_{\mathrm{P}}$ (Opdyke et al. 2009), we assumed that reduction was not a significant factor in our isotope data. We recognize that the mid-point between the $S_{\mathrm{P}}$ for nitrification or fungal dentrification (nitrification/fungal dentrification, $34.8 \%$ ) and denitrification (- 3.9 $\%$ ) is $15.5 \%$ (Lewicka-Szczebak et al. 2017). Consequently, flux chamber samples with $S_{\mathrm{P}}$ above the global average for the troposphere, $18.7 \pm 2.2 \%$ o (Yoshida and Toyoda 2000) exceed that of the midpoint and predominantly derive from nitrification/fungal dentrification. Production of $\mathrm{N}_{2} \mathrm{O}$ from denitrification increases as $S_{\mathrm{P}}$ declines below $18.7 \%$.

We used laser spectroscopy to determine $\mathrm{N}_{2} \mathrm{O}$ concentration and $S_{\mathrm{P}}$ for an investigation of emissions and processes leading to $\mathrm{N}_{2} \mathrm{O}$ production in a historically never tilled (over 50 years) successional grassland in Okemos, MI USA and at the Kellogg Biological Station's Great Lakes Bioenergy Research Center Biofuel Cropping Experiment (KBS BCSE) in Hickory Corners, MI USA. Our spectroscopic approach did not require preconcentration allowing us to analyze all samples regardless of concentration. We were specifically interested in the influence of tilling in the grassland and fertilizer application at KBS BCSE on the origins of $\mathrm{N}_{2} \mathrm{O}$ that accumulated in flux chambers. The grassland tilling experiment was conducted over a year and the agricultural fertilization experiment over the growing season beginning one month after fertilization until just prior to harvest. The $\mathrm{N}_{2} \mathrm{O}$ accumulating in flux chambers represents a mixture of soil derived and atmospheric $\mathrm{N}_{2} \mathrm{O}$ that was present prior to sealing the chambers. In addition to flux chamber sampling we were interested in variation in atmospheric $\mathrm{N}_{2} \mathrm{O} S_{\mathrm{P}}$. Specifically we asked the following questions. 1) Does the flux and source of $\mathrm{N}_{2} \mathrm{O}$ change as a consequence of a single tilling in a successional grassland? 2) Does $\mathrm{N}_{2} \mathrm{O}$ flux and source change subsequent to fertilization of corn (Zea mays)?
3) In the perennial biofuel crop switchgrass (Panicum virgatum), does fertilization change the $\mathrm{N}_{2} \mathrm{O}$ flux and source relative to non-fertilized switchgrass? and 4) Does the $S_{\mathrm{P}}$ of atmospheric $\mathrm{N}_{2} \mathrm{O} 2 \mathrm{~m}$ above surface vary and is it influenced by soil microbial processes? An important overarching requirement in addressing these questions was the development of a careful and accurate calibration procedure, evaluation of drift and ensuring accuracy of our spectroscopic approach.

\section{Methods}

Flux chamber design and sample collection

For the grassland tilling experiment cylindrical polyvinyl chloride flux chambers (surface area $=486$ $\mathrm{cm}^{2}$, headspace volume $=8 \mathrm{~L}$ ) were buried $5 \mathrm{~cm}$ deep in soil and covered with an airtight PVC lid sealed with a viton O-ring and in the agricultural fertilization experiment cylindrical stainless steel flux chambers ( surface area $=641 \mathrm{~cm}^{2}$, headspace volume $=11.4 \mathrm{~L}$ ) were also buried $5 \mathrm{~cm}$ deep in soil and covered with an airtight PVC lid sealed with a viton O-ring. Flux chambers were maintained at atmospheric pressure by a piece of coiled stainless-steel tubing $(0.5 \mathrm{~m} \mathrm{X}$ $0.32 \mathrm{~cm}$ OD and $0.18 \mathrm{~cm}$ ID) extending from the interior to exterior of the chamber. Samples consisting of air and accumulating soil gases from the headspace of the flux chamber were collected after $24-48 \mathrm{~h}$ in the grassland tilling experiment and $20 \mathrm{~min}$ to $6 \mathrm{~h}$ in the agricultural fertilization experiment (Table S1, Table S2). The headspace was sampled with a $1 \mathrm{~L}$ gas tight syringe (SGE Analytical Science) fitted to the chamber via a small piece of stainless-steel tubing ( $5 \mathrm{~cm}$ length, $0.64 \mathrm{~mm} \mathrm{OD}$ ) and $5 \mathrm{~cm}$ of $0.6 \mathrm{~mm} \mathrm{OD}$ polyurethane tubing.

Site description and sampling schedule

For the tilling experiment we analyzed 159 samples consisting of 102 flux chamber and 57 atmosphere samples taken over one year (Table S1). The experiment was conducted in a historically never tilled (over 50 years) successional grassland in Okemos, Michigan over soils classified as Conover Loam by the USDA. Six flux chambers were evenly placed within a $48 \mathrm{~m}^{2}$ plot. Prior to their emplacement the soil beneath three randomly selected chambers was rotary tilled to 
$10 \mathrm{~cm}$ depth and the soil beneath the remaining three was undisturbed. Flux chamber sampling began on October 1, 2017, one day after tilling. Samples were subsequently collected on October 9, 27 and 29 of 2017 and then at $\sim 4$-week intervals until September 16, 2018. Immediately after collecting samples from flux chambers, atmosphere adjacent to the chamber plot was sampled at $\sim 2 \mathrm{~m}$ above the ground using a $1 \mathrm{~L}$ gas tight syringe. Atmospheric samples collected in this way were placed in Tedlar ${ }^{\circledR}$ bags prior to analysis in the laboratory. Beginning in November of 2017, additional atmosphere samples were taken approximately $100 \mathrm{~m}$ east of the plot used for the tilling experiment. Meteorological conditions for each sampling day appear in Table S1.

For the agricultural fertilization experiment we analyzed 64 samples consisting of 54 flux chamber and 10 atmospheric samples (Table S2). The experiment was conducted at the KBS BCSE, which was established in 2008. Soils at KBS are primarily Kalamazoo loam (USDA soil classification: FineLoamy, Mixed, Semiactive, Mesic Typic Hapludalfs). The KBS BCSE consists of a randomized complete block design with 5 replicated blocks of up to 10 cropping systems or treatments, each in $30 \times 40 \mathrm{~m}$ plots (Fig. 1). One flux chamber was placed in each of 4 different corn plots. Switchgrass plots contained fertilized and unfertilized subplots that were $25.4 \mathrm{~m} \times 40 \mathrm{~m}$ and $4.6 \mathrm{~m} \times 40 \mathrm{~m}$, respectively. Two flux chambers were placed in each of 4 different switchgrass plots with 1 chamber in the fertilized and the other in the unfertilized subplot. Switchgrass was fertilized on May 16, 2019 with 28\% urea-ammonium nitrate at $16.1 \mathrm{~L} / \mathrm{km}^{2}$. Corn was fertilized on June 5 , 2019 with $28 \%$ urea-ammonium nitrate at $16.1 \mathrm{~L} / \mathrm{km}^{2}$. Sampling began $\sim 1$ month after fertilization in all plots and was completed prior to harvest and no other management practice (e.g. tillage) occurred in these or adjacent plots during the study. Flux chambers in unfertilized and fertilized switchgrass were sampled at $\sim$ monthly intervals beginning on June 18, 2019 for 5 months. Atmosphere samples were taken northeast of plot G5R5 at $2 \mathrm{~m}$ above ground (Fig. 1). Flux chambers in corn were sampled at $\sim$ monthly intervals beginning on July 8, 2019 for 4 months. Samples were taken with a $1 \mathrm{~L}$ gas-tight syringe and the gas placed in Tedlar ${ }^{\circledR}$ bags as previously described in Flux Chamber Design and Sample Collection.
Meteorological conditions for each sampling day appear in Table S2.

$\mathrm{N}_{2} \mathrm{O}$ flux calculations

$\mathrm{N}_{2} \mathrm{O}$ concentration was determined based on a linear regression of concentration vs. detector response within an ABB Los Gatos Research Incorporated (LGR) off-axis cavity enhanced spectroscopic analyzer using standards of known $\mathrm{N}_{2} \mathrm{O}$ concentration (known via measurement and verified by Shimadzu GC-2014, GC-ECD). Using these concentrations and the air temperature at the time of sampling, $\mathrm{N}_{2} \mathrm{O}$ fluxes were calculated based on an increase in $\mathrm{N}_{2} \mathrm{O}$ concentration from that of air using the global average of 330 ppbv (WMO Greenhouse Gas Bulletin no. 14) during the incubation time (20 min to $48 \mathrm{~h}$ ).

Site preference measurements

The LGR was used to determine the $S_{\mathrm{P}}$ of $\mathrm{N}_{2} \mathrm{O}$ at concentrations ranging from near atmospheric $(\sim 330$ ppbv) to $\sim 4000$ ppbv. $\mathrm{N}_{2} \mathrm{O}$ standards analyzed to calibrate the LGR were made from two pure $\mathrm{N}_{2} \mathrm{O}$ tank standards which were isotopically characterized with respect to the USGS51 and USGS52 isotopic reference materials on an IsoPrime100 stable isotope ratio mass spectrometer (IRMS) interfaced to a TraceGas inlet system (TGIRMS, Elementar; Mt. Laurel, NJ) (Sutka et al. 2003; Ostrom et al. 2018). The TraceGas inlet system collectively removes $\mathrm{CO}_{2}$ and water and cryogenically focuses $\mathrm{N}_{2} \mathrm{O}$ onto a gas chromatographic column for introduction to the mass spectrometer. The two tank standards, $24.4 \%$ and -0.7 $\%$ in $S_{\mathrm{P}}$, were diluted into a septum fitted glass bulb filled with UHP $\mathrm{N}_{2}$ (Airgas) and these served as working standards. Working standards with intermediate $S_{\mathrm{P}}$ values were made from a mixture of the two tank standards. The working standards were further diluted into 1 L Tedlar ${ }^{\circledR}$ bags (Restek) previously filled with Ultra Zero Air (Airgas) and these served as our calibration standards with varying $S_{\mathrm{P}}$ and $\mathrm{N}_{2} \mathrm{O}$ concentration. To ensure mixing of gases, standards were allowed to equilibrate for at least $1 \mathrm{~h}$ prior to analysis and samples were analyzed within $48 \mathrm{~h}$ of collection.

Prior to their introduction into the LGR, the $1 \mathrm{~L}$ of gas from samples or standards were passed through a Nafion (Perma Pure) membrane $(4.3 \mathrm{~m})$, for water 

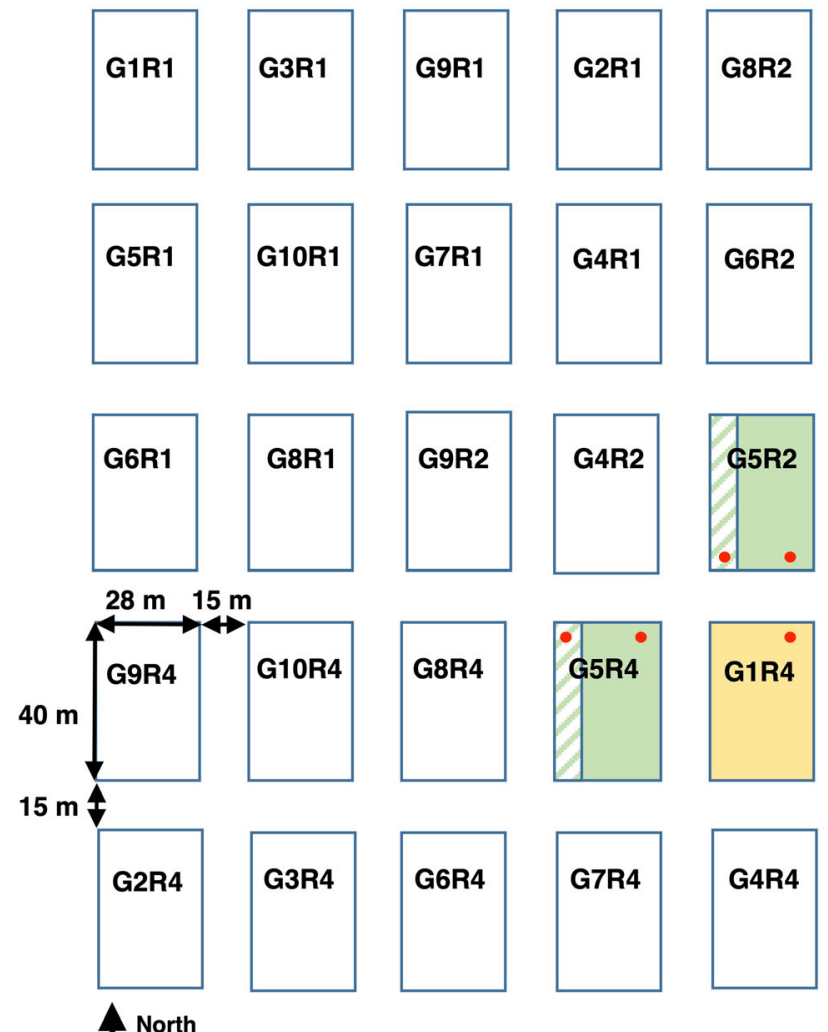

North

Fig. 1 Arrangement of plots at the Kellogg Biological Station Biofuel Cropping System Experiment (KBS BCSE) showing locations of flux chambers (red circle) in corn (yellow shaded rectangle) and switchgrass (green shaded rectangle) with fertilized (solid green shading) and unfertilized (striped) subplots. The vertical arrow in the lower left indicates geographic north. The location of atmosphere samples is designated by a blue star. Plots are $40 \times 28 \mathrm{~m}$ with $15 \mathrm{~m}$ between. Crop designations and replicate number e.g. R1 for replicate 1) appear within plots: continuous corn with stover

removal, and two chemical traps interfaced to the instruments. The traps included a carbosorb (Elemental Microanalysis) trap for removal of $\mathrm{CO}_{2}(6 \mathrm{~mm}$ ID $\times 20 \mathrm{~cm})$ and a trap to remove trace organic contaminants and residual water $(6 \mathrm{~mm}$ ID $\times 40 \mathrm{~cm})$ consisting of activated carbon $(9 \mathrm{~cm})$ and preconditioned silica gel (60 ̊, 200-400 mesh particle size, Sigma-Aldrich). The silica gel was preconditioned at $\sim 180{ }^{\circ} \mathrm{C}$ under $100 \mathrm{~mL} / \mathrm{min}$ UHP $\mathrm{N}_{2}$ flow for 24-48 $\mathrm{h}$ and subsequently cooled to room temperature under $100 \mathrm{~mL} / \mathrm{min}$ UHP $\mathrm{N}_{2}$ flow for at-least $1 \mathrm{~h}$ before use. Analysis time for each sample was $10 \mathrm{~min}$ of which the last 6 min were used to determine $S_{\mathrm{P}}$ and
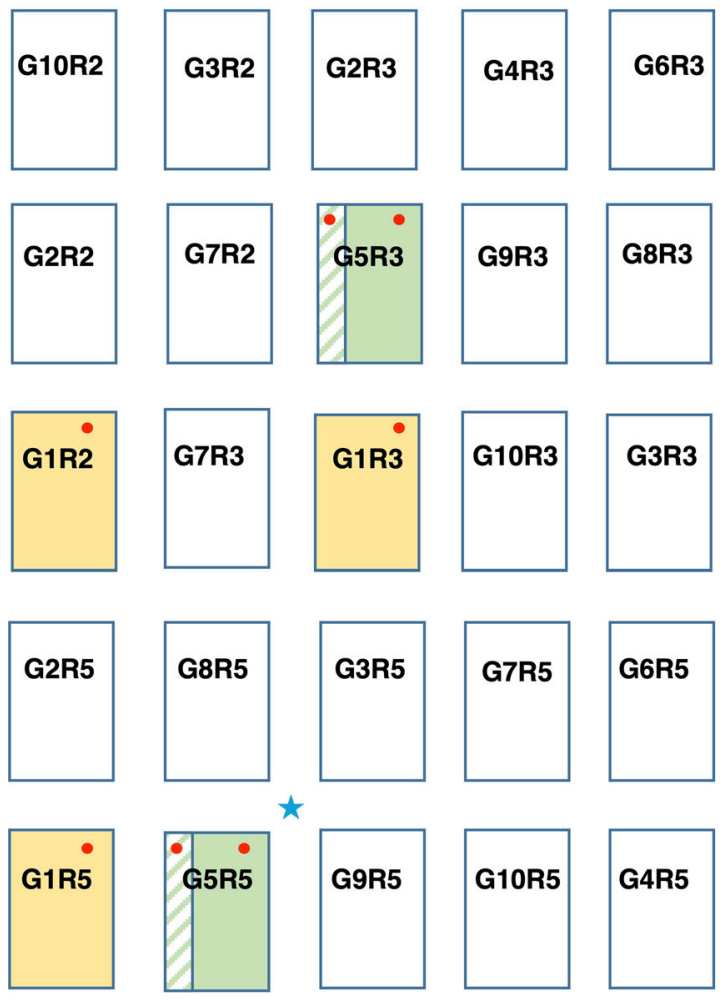

\section{Fertilized Switchgrass $\quad$ Flux Chamber \\ Unfertilized Switchgrass $\star$ Atmosphere Sampling \\ Fertilized Corn}

removal (G1), continuous energy sorghum (photoperiod-sensitive hybrid ES5200, G2), and energy sorghum (photoperiod insensitive hybrid TAM 17,900) plus cover crop (G3), and six perennial treatments: switchgrass (G5, Panicum virgatum), miscanthus (G6, Miscanthus x giganteus), poplar (G8, "NM6", Populus nigra x Populus maximowiczii), native grasses (a mix of 4 species; G7), early successional vegetation (G9), and restored prairie (G10). Thus, G1R2 is the second replicate of corn in the GLBRC-BCSE. (Color figure online)

$\mathrm{N}_{2} \mathrm{O}$ concentration based on non-drifting detector signals.

As described in the discussion, our calibration procedure typically included at least 18 primary standards whose $S_{\mathrm{P}}$ and $\mathrm{N}_{2} \mathrm{O}$ concentration encompassed the range observed within the samples analyzed in triplicate. "Check" standards, preferably with an intermediate $S_{\mathrm{P}}$ and $\mathrm{N}_{2} \mathrm{O}$ concentration, were also analyzed to evaluate accuracy and drift. Further evaluation of accuracy was made by comparing the isotope values of three isotopically unique standards prepared at $\sim 1600 \mathrm{ppbv}$ on the LGR and TGIRMS 
and by measuring companion atmospheric samples on the LGR and TGIRMS.

Because flux chamber and atmospheric samples were collected in Tedlar ${ }^{\circledR}$ bags and stored for up to $48 \mathrm{~h}$, we evaluated the influence of storage time on $\mathrm{N}_{2} \mathrm{O}$ concentration and $S_{\mathrm{P}}$. In this experiment, 42 Tedlar bags were filled with the same gas and analyzed in quadruplicate on the first day and on days 2 through 7.

\section{Statistical analysis}

We performed statistical analyses with JMP Pro (SAS version 14.3). ANOVA was used to (1) test for differences in $S_{\mathrm{P}}$ between the TGIRMS and LGR, (2) test the effect of storage time on $S_{\mathrm{P}}$ of isotopically characterized standards; (3) evaluate relationships between expected and observed $\mathrm{N}_{2} \mathrm{O}$ concentration; assess the relationship between expected $S_{\mathrm{P}}$ and observed $S_{\mathrm{P}}$ and observed $\mathrm{N}_{2} \mathrm{O}$ concentration; and (4) test the effect of sampling date (time after fertilization) and/or fertilizer treatment on $S_{\mathrm{P}}$ or $\mathrm{N}_{2} \mathrm{O}$ flux. When required pairwise comparisons were evaluated using Tukey's HSD test. Descriptive statistics and ANOVA are used to discuss variation in atmospheric $\mathrm{N}_{2} \mathrm{O}$ data.

\section{Results and discussion}

Spectroscopic approach

With the promise of providing continuous real-time data, laser spectroscopy has drawn great attention (Decock and Six 2013; Harris et al. 2020). We did not have confidence in the ability of laser spectroscopy to produce accurate data in the field. Aside from the challenges of providing stable electrical sources, our calibration requires several primary tank standards all of which can't, simply, be interfaced to the instrument particularly under field conditions. The introduction of standard gases from tanks can easily result in minor variations in pressure within the analyzer cavity and results in substantive, unpredictable and non-reproducible instability that prevents accurate calibration. Thus, we developed a Tedlar® bag sampling approach that avoids pressure related issues.

The initial requirement of our approach was to develop a statistical model to predict $\mathrm{N}_{2} \mathrm{O}$ concentration and $S_{\mathrm{P}}$ via calibration. Our calibration typically included at least 18 primary standards whose $S_{\mathrm{P}}$ and $\mathrm{N}_{2} \mathrm{O}$ concentration closely encompassed the range observed within the samples (e.g. Table S3). The 18 primary standards included 3 standards of unique $S_{\mathrm{P}}$ between $\sim-1$ to $24 \%$, comprised at least $2 \mathrm{~N}_{2} \mathrm{O}$ concentrations between $350 \mathrm{ppbv}$ and $\sim 2300 \mathrm{ppbv}$ and were analyzed in triplicate. These primary standards were used for statistical models to predict $\mathrm{N}_{2} \mathrm{O}$ concentration and $S_{\mathrm{P}}$ of samples. To evaluate accuracy in $S_{\mathrm{P}}$ and $\mathrm{N}_{2} \mathrm{O}$ concentration predicted by the model, we also analyzed "check" standards, preferably with values that were intermediate to and, thus, independent from those of the primary standards (Table S3). By analyzing check standards over time, we could also assess drift in isotope values. Isotopic drift was never observed during our $\sim 8 \mathrm{~h}$ analysis period. Based on check standards our entire data set shows an average reproducibility and accuracy of $\mathrm{N}_{2} \mathrm{O}$ concentration as $7 \mathrm{ppbv}$ and $1.6 \%$, respectively. The average reproducibility and accuracy of $S_{\mathrm{P}}$ for all check standards are $0.7 \%$ and $1.0 \%$, respectively. Reproducibility is determined from the average of our check standards. Accuracy is defined as the difference between the known concentration or $S_{\mathrm{P}}$ of the check standard and that predicted by statistical modeling.

We were particularly concerned with our assessment of accuracy for $S_{\mathrm{P}}$. Thus, in addition to check standards, we made two additional assessments of $S_{\mathrm{P}}$ accuracy. First, we compared the isotope values of three isotopically unique standards prepared at 1600 ppbv on the LGR and TGIRMS. The paired data for the TGIRMS and LGR showed a difference of $\leq 0.5 \%$. For the TGIRMS and LGR, respectively the $S_{\mathrm{P}}$ values for these three standards are: $24.2 \pm 0.1$ $\%$ o, $24.1 \pm 0.4 \%$; $11.5 \pm 0.1 \%$, $11.7 \pm 0.1 \%$ and $-1.2 \pm 0.4 \%$, $-0.7 \pm 0.1 \%$ o (Table S4). Second, we confirmed accuracy at low $\mathrm{N}_{2} \mathrm{O}$ concentration by measuring companion atmospheric samples on the LGR and TGIRMS. The results for LGR are $310 \pm 1$ ppbv and $15.1 \pm 0.4 \%(\mathrm{n}=3)$ and TGIRMS are $307 \pm 3 \mathrm{ppbv}$ and $15.7 \pm 0.4 \%$ o $(\mathrm{n}=3)$, for $\mathrm{N}_{2} \mathrm{O}$ concentration and $S_{\mathrm{P}}$ respectively. ANOVA confirmed that the difference between instruments in concentration and $S_{\mathrm{P}}$ was not significant: $\mathrm{p}=0.760$ and 0.421 for $S_{\mathrm{P}}$ and $\mathrm{N}_{2} \mathrm{O}$ concentration, respectively. These results confirm our approach for measuring samples at low concentration $(\sim 320$ ppbv $)$ without preconcentration. 
Because our approach involved placing standards or samples in Tedlar ${ }^{\circledR}$ bags, we investigated the influence of storage time on concentration and $S_{\mathrm{P}}$ (Table S5). Because low concentration standards would be the most susceptible to error from ingress of air and are the most difficult to measure, this experiment used isotopically characterized standards of known concentration at near atmospheric concentration. The $\mathrm{N}_{2} \mathrm{O}$ concentration showed a significant correlation with time $(\mathrm{p}<0.001)$ over $7 \mathrm{~d}$ but the model accounted for only a small portion of the variance $\left(\mathrm{R}^{2}=0.38\right)$. Note that the difference in $\mathrm{N}_{2} \mathrm{O}$ concentration between days 0.1 and $7.1,9 \mathrm{ppbv}$, is not greatly higher than our reproducibility of $7 \mathrm{ppbv}$ making it difficult to conclude there is a strong effect of time regardless of the ANOVA results. Because our samples were never stored for more than 2 days and there was no influence of time on concentration during that time period (difference between day 0.1 and $4=0.4 \mathrm{ppbv}$ ) we did not make any correction for storage time. In contrast to the concentration data the effect of time on $S_{\mathrm{P}}$ was not significant. This suggested that standards in Tedlar ${ }^{\circledR}$ bags retain their isotopic integrity for up to $7 \mathrm{~d}$ (Table S5). Although our results demonstrate the potential for sample storage, we recommend that every lab evaluate storage independently.

Because the LGR can be used to analyze atmospheric samples without preconcentration and the sample analysis time on the LGR (10 $\mathrm{min})$ is much shorter than on the TGIRMS (up to $60 \mathrm{~min}$ ), spectroscopic analysis is an appealing alternative to mass spectrometry. However, the time required for calibration, $\geq 3.5 \mathrm{~h}$, and preparing standards, $\sim 6 \mathrm{~h}$, must be accounted for. Regardless of which instrument is used, both require calibration with isotopically distinct standards that encompass the range of the samples, check standards, evaluation of drift, removal of interfering gases and evaluation of the effects of procedural methods (e.g. storage). Calibration is problematic because isotopically distinct standards are not readily available. In addition, given our extensive calibration modeling efforts, we recommend rigorous models that involve 6 or more standards analyzed in triplicate and check standards analyzed throughout the the day. Models that fall short of this can incorporate large errors. Because all of our analyses were performed manually, future efforts to interface isotopically distinct tanks to the LGR from an automated valving system designed to prevent pressure changes would markedly increase the efficiency of the spectroscopic approach.

\section{Grassland tilling experiment}

Our first experiment investigated whether the flux and source of $\mathrm{N}_{2} \mathrm{O}$ change as a consequence of a single tilling event in a successional grassland and included 102 chamber samples. The data set showed remarkable variation with a wide range in $\mathrm{N}_{2} \mathrm{O}$ flux $(0-1.9 \mathrm{~g}$ $\left.\mathrm{N}_{2} \mathrm{O}-\mathrm{N} \mathrm{ha}{ }^{-1} \mathrm{~d}^{-1}\right)$ and $S_{\mathrm{P}}(-1.8$ to $25.1 \%$ ) for 100 samples (Fig. 2). The two remaining samples from January 11, 2018 included one with a flux of $1.0 \mathrm{~g}$ $\mathrm{N}_{2} \mathrm{O}-\mathrm{N}$ ha ${ }^{-1} \mathrm{~d}^{-1}$ and a high $S_{\mathrm{P}}$ that could not be determined because it was far outside the range of our standards and another sample had a high flux of $4.0 \mathrm{~g}$ $\mathrm{N}_{2} \mathrm{O}-\mathrm{N} \mathrm{ha}{ }^{-1} \mathrm{~d}^{-1}$ and $S_{\mathrm{P}}$ of $0.6 \%$. High temporal as well as spatial variation in $\mathrm{N}_{2} \mathrm{O}$ flux is well recognized and contributes to uncertainty in $\mathrm{N}_{2} \mathrm{O}$ emission rates, particularly in agricultural systems (Aneja et al. 2019; Hénault et al. 2012; Wang et al. 2020). Many factors have been attributed to variation in $\mathrm{N}_{2} \mathrm{O}$ flux including temperature associated changes in gas solubility and diffusivity, soil moisture, microbial activity, availability of carbon and inorganic nitrogen substrates, disruption of microaggregates, and release of $\mathrm{N}_{2} \mathrm{O}$ trapped below ice (Congreves et al. 2019; Kim et al. 2012; Ruan and Robertson 2017).

To determine if tilling influenced flux, we performed an analysis of variance (ANOVA) with treatment, sampling date and sampling date $\mathrm{x}$ treatment as predictor variables of flux. The model identified sampling date as the only significant term $(\mathrm{p}=0.006)$. This contrasts with previous work in a historically never-tilled grassland which showed marked increases in $\mathrm{N}_{2} \mathrm{O}$ flux upon initiation of annual tillage (Grandy and Robertson 2006a, b). The absence of a till effect in our data is likely related to the high variance in flux within and between sampling dates within a treatment. In our till chambers, the highest fluxes were observed in the late fall (October 2017) and late spring (May 2018) when microbial processes were likely not inhibited by dry or frozen soils (e.g. for the study location, October's average low temperature is $5{ }^{\circ} \mathrm{C}$ and monthly precipitation is $6.4 \mathrm{~cm}$ ). In no-till, two of the three highest fluxes occurred during a thaw event on January 11, 2018 (Fig. 2). While previous studies identify freeze thaw cycles as important to 


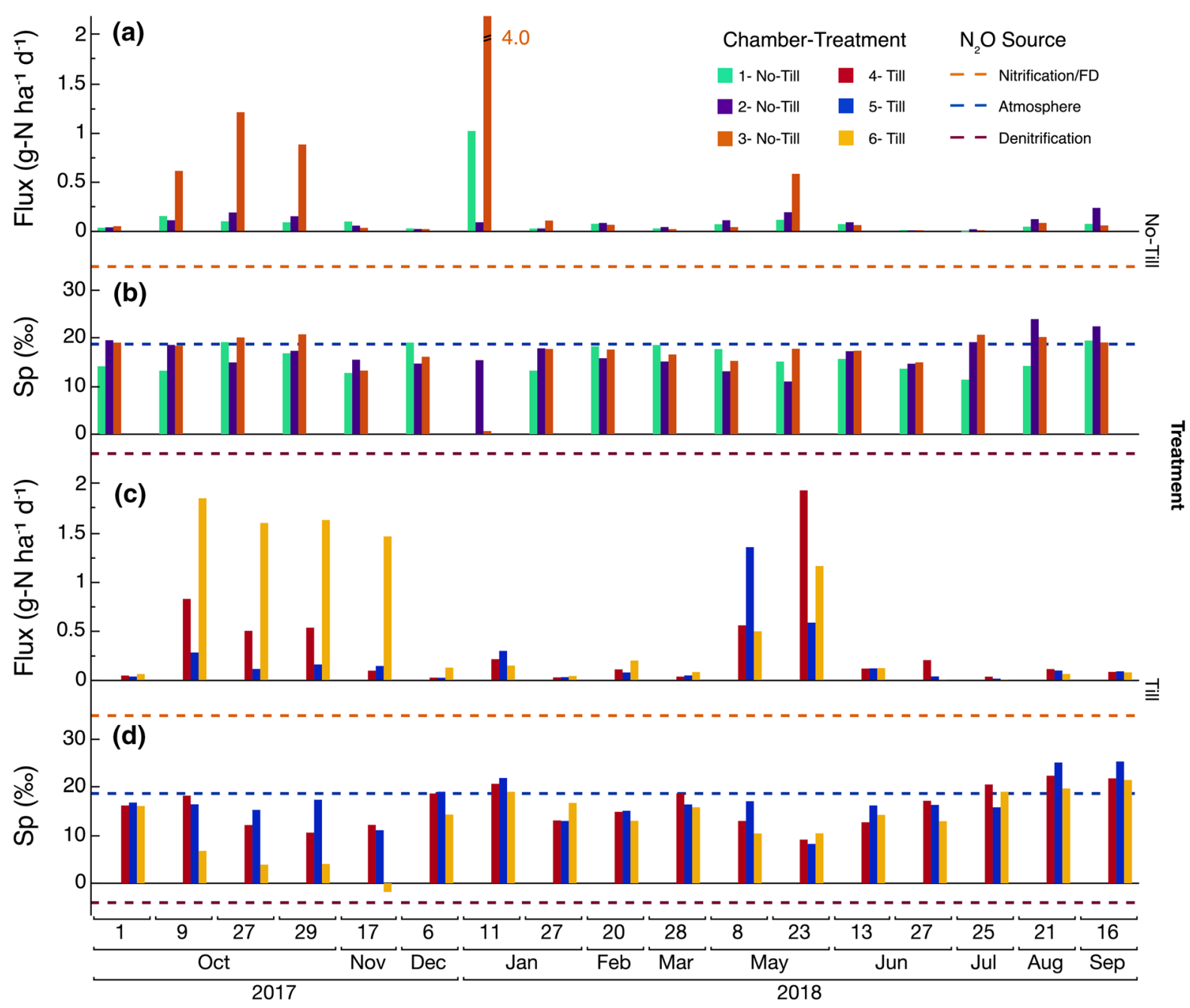

Fig. 2 Flux and Site Preference $\left(S_{\mathrm{P}}\right)$ of $\mathrm{N}_{2} \mathrm{O}$ in samples of flux chamber headspace in the grassland experiment conducted in Okemos, MI between October 1, 2017 and September 16, 2018. Panels (a) and (b) are data from no till chambers $(1,2,3)$. Panels (c) and (d) are data from tilled chambers $(4,5,6)$. The dashed lines in panels (b) and (d) represent the average $S_{\mathrm{P}}$ value of

$\mathrm{N}_{2} \mathrm{O}$ emissions (Congreves et al. 2019; Flesch et al. 2018; Smith 2017) the observation of a fourfold difference in flux equivalent to $\sim 3.9 \mathrm{~g} \mathrm{~N}_{2} \mathrm{O}-\mathrm{N}$ ha $^{-1}$ $\mathrm{d}^{-1}$ between two chambers separated by $\sim 2 \mathrm{~m}$ is remarkable (Fig. 2). Large differences in flux on a single sampling date were not uncommon in this data set. This observation contributes to growing awareness that flux is influenced by factors on scales much smaller than the ecosystem scale considered by most studies (Kravchenko and Robertson 2015; Kravchenko et al. 2017). Such factors include water filled nitrification/fungal denitrification (Nitrification/FD), denitrification, and global average for the atmosphere, $34.8 \%$ o, $-3.9 \%$ and $18.7 \%$ respectively (Lewicka-Szczebak et al. 2017). Bars appear in order of chambers 1 to chamber 6 and are centered over the sampling date. (Color figure online)

pore space, oxygen content, temperature, organic carbon content, inorganic nitrogen supply, and numerous physical soil properties such as connectivity and tortuosity (Aneja et al. 2019; Grandy and Robertson 2006a, b; 2007; Kravchenko et al. 2018; Neftel et al. 2007).

The issue of variability and sample size go hand-inhand. The number of chambers in our plot represent the maximum that could be placed in the area without introducing artificially high fluxes associated with increased pressure from foot traffic during sampling. 
While a larger plot size could have accommodated additional flux chambers and increased our sample size, the choice of small plot size represented a tradeoff between sample analysis time and the time required for careful and detailed analytical approaches necessary for our study. Thus, we are conservative with the interpretation of data. As will be elaborated upon, despite sample size the flux and $S_{\mathrm{P}}$ data clearly show that variation occurs within a small area, offer interesting trends in $S_{\mathrm{P}}$, constitute a long-term study and represent one of the few in-situ mechanistic approaches to a field site study of $\mathrm{N}_{2} \mathrm{O}$ flux and $S_{\mathrm{P}}$.

We used $S_{\mathrm{P}}$ to investigate the influence of a single tilling event on the source of $\mathrm{N}_{2} \mathrm{O}$ in the grassland. Similar to the variation in flux, we observed high variation in $\mathrm{N}_{2} \mathrm{O} S_{\mathrm{P}}$ among sampling dates and between chambers analyzed on a single sampling date (Fig. 2). For example, the $\mathrm{N}_{2} \mathrm{O}$ from the highest flux in January 2018 had a $S_{\mathrm{P}}$ of $0.6 \%$ whilst the other two no-till chambers had $S_{\mathrm{P}}$ values that were substantially higher including one value of $15.3 \%$ and another that was much beyond the maximum of our standards (24.4 $\%$ ) and could not be estimated. With the exception of microbial pathways of $\mathrm{N}_{2} \mathrm{O}$ production and water filled pore space, we understand little regarding the specific controls on $S_{\mathrm{P}}$ (Ostrom and Ostrom 2012). Elevated water filled pore space and labile organic matter results in an increased amount of $\mathrm{N}_{2} \mathrm{O}$ from denitrification relative to nitrification (JinuntuyaNortman et al. 2008; Kravchenko et al. 2018). The winter thaw of 2018 resulted in visibly soggy soils and large amounts of surface water adjacent to the study site suggesting saturated soil conditions and high WFPS. However, a dominance of $\mathrm{N}_{2} \mathrm{O}$ from denitrification was not evident in all flux chambers.

To determine how a single tilling event influenced $S_{\mathrm{P}}$, we used an ANOVA with treatment, flux and treatment x flux as predicter variables of $S_{\mathrm{P}}$. Only flux and the interaction between flux and treatment were significant $(\mathrm{p}<0.001$ and $\mathrm{p}=0.006$, respectively). For visual purposes we plotted $S_{\mathrm{P}}$ vs. flux for the two treatments along with lines of fit (Fig. 3). We excluded the exceptionally high flux sample in no-till as there was a large gap $\left(2.8 \mathrm{~g} \mathrm{~N}_{2} \mathrm{O}-\mathrm{N} \mathrm{ha}^{-1} \mathrm{~d}^{-1}\right)$ between this and the next highest flux in that treatment. There appears to be a direct relationship between $S_{\mathrm{P}}$ and flux when flux was $>0.6 \mathrm{~g} \mathrm{~N}_{2} \mathrm{O}-\mathrm{N} \mathrm{ha}^{-1} \mathrm{~d}^{-1}$ in no-till and the reverse is true for till when the flux was $\geq 0.5 \mathrm{~g}$ $\mathrm{N}_{2} \mathrm{O}-\mathrm{N} \mathrm{ha}{ }^{-1} \mathrm{~d}^{-1}$ (Fig. 3). Although fluxes $>0.6 \mathrm{~g}$
$\mathrm{N}_{2} \mathrm{O}-\mathrm{N}$ ha ${ }^{-1} \mathrm{~d}^{-1}$ are scant in no-till, four of the five $S_{\mathrm{P}}$ values $\geq 18 \%$ associated with high flux events occurred only in no-till (October of 2017 or May of 2018). The high $S_{\mathrm{P}}$ of these samples likely reflects an important contribution of $\mathrm{N}_{2} \mathrm{O}$ from nitrification/fungal denitrification In till, high flux-low $S_{\mathrm{P}}$ values occurred in October and May (e.g. yellow bars in October and May in Fig. 2 c,d) and are consistent with $\mathrm{N}_{2} \mathrm{O}$ derived from denitrification. As a consequence of October's precipitation (average monthly rainfall of $6.4 \mathrm{~cm}$ ) soils at our study site are, characteristically, more wet than during the earlier fall and summer and May represents a period when frosts become infrequent and soils are commonly thawed and moist. Such conditions can promote low oxygen soil environments that are conducive to denitrification. A single tilling event in a grassland can disrupt soil aggregates and increase intra-aggregate light organic matter, a potential substrate for denitrification (Grandy and Robertson 2006b, a). Taken together, this poses the possibility that grasslands experiencing tillage for the first time are more likely to produce $\mathrm{N}_{2} \mathrm{O}$ from denitrification as soils become moist.

The observation that $S_{\mathrm{P}}$ appeared to vary as a function of flux directly in no-till and indirectly in till was a salient feature of our data set and may suggest a fundamental difference in the control on $\mathrm{N}_{2} \mathrm{O}$ sources in the two treatments. However, our ability to interpret $\mathrm{N}_{2} \mathrm{O}$ sources would benefit from additional $S_{\mathrm{P}}$ data, particularly from periods of high flux. Given the episodic nature of $\mathrm{N}_{2} \mathrm{O}$ flux, such data is difficult to come by with periodic sampling. Moreover, the ability to interpret trends in $S_{\mathrm{P}}$ data is hindered by the paucity of mechanistic studies aimed at evaluating the influence of individual physical and biological soil properties on $\mathrm{N}_{2} \mathrm{O}$ flux and $S_{\mathrm{P}}$. Such studies would be particularly valuable for understudied ecosystems such as undisturbed temperate grasslands that are often converted to cropland or lost to development.

Agricultural fertilization experiment: corn

Agriculture offers a setting where management practices can, potentially, be modified to influence microbial processes. The KBS BCSE offered a setting where we could inquire whether $\mathrm{N}_{2} \mathrm{O}$ flux and source change subsequent to fertilization. The 16 chamber samples from corn showed a wide range in $\mathrm{N}_{2} \mathrm{O}$ flux (0.2-60.7 g N $_{2} \mathrm{O}-\mathrm{N}$ ha ${ }^{-1} \mathrm{~d}^{-1}$ ) (Fig. 4). Corn did not 
Fig. 3 Flux and Site Preference $\left(S_{\mathrm{P}}\right)$ of $\mathrm{N}_{2} \mathrm{O}$ in samples of flux chamber headspace in the grassland experiment conducted in Okemos, MI showing the relationship between the two variates separated by no till and tilled chambers. Linear fits are for visual purposes and account for 9 and $44 \%$ of the variance for no-till and till, respectively. Shaded area is the $95 \%$ confidence interval. The dashed lines represent the average $S_{\mathrm{P}}$ value of nitrification/fungal denitrification (Nitrification/ FD), denitrification, and global average for the atmosphere, $34.8 \%$, - 3.9 $\%$ and $18.7 \%$ respectively (Lewicka-Szczebak et al. 2017). (Color figure online)

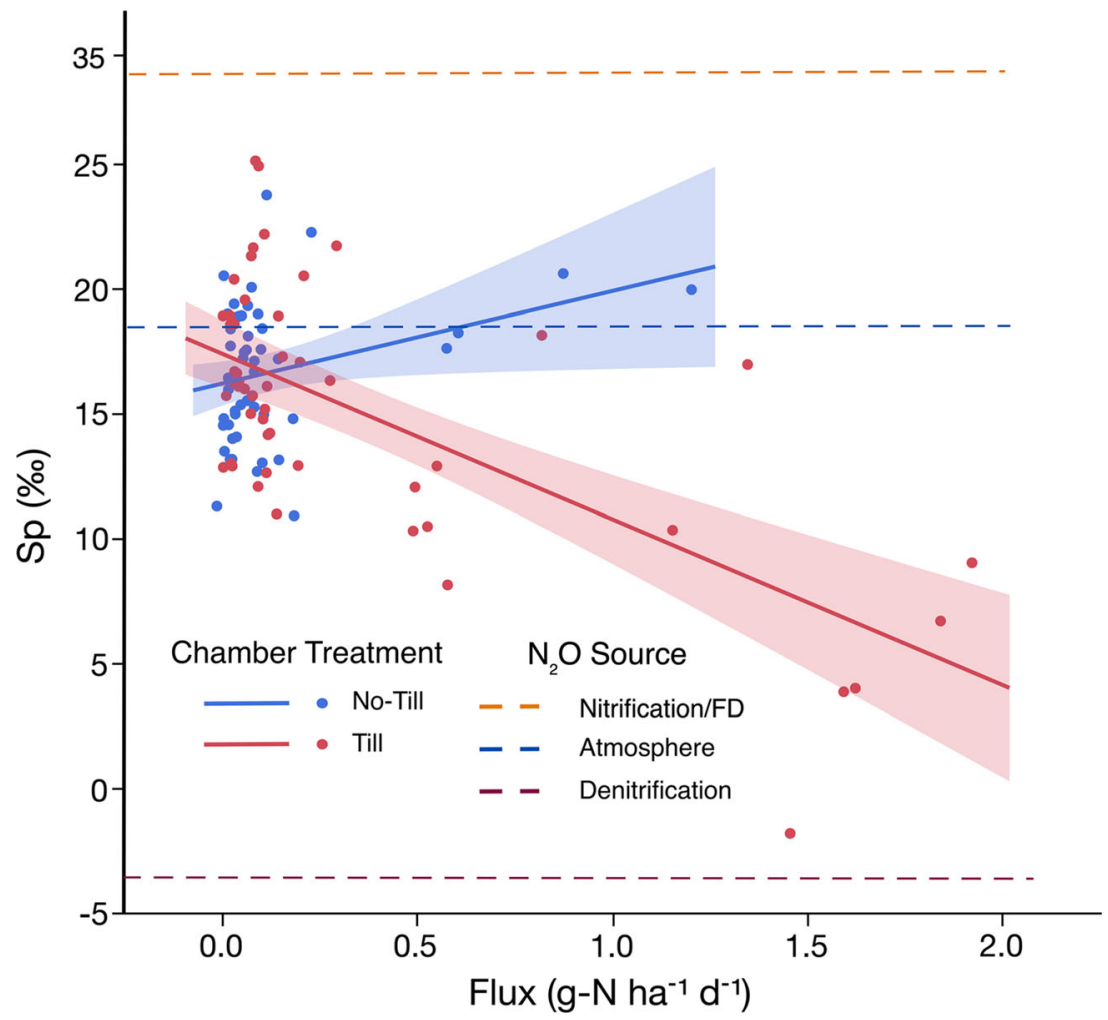

have a non-fertilizer treatment, so we investigated whether $\mathrm{N}_{2} \mathrm{O}$ flux or source, responded to time after fertilization (i.e. sampling date). Time after fertilization had a significant influence on flux $(\mathrm{p}=0.008)$ and accounted for $61 \%$ of the variance. The high flux on the first sampling date, July 8, 2019 was significantly different from all subsequent sampling dates $(\mathrm{p}<0.020)$. These data suggest that high $\mathrm{N}_{2} \mathrm{O}$ fluxes occur in response to fertilization and rapidly taper off during the growing season. Large fluxes in corn subsequent to fertilization have been observed previously (Oates et al. 2015). While numerous variables influence $\mathrm{N}_{2} \mathrm{O}$ flux, fertilization, temperature, waterfilled pore space, and the concentration of ammonium and nitrate are known to influence $\mathrm{N}_{2} \mathrm{O}$ emissions at KBS BCSE (Duncan et al. 2019; Oates et al. 2015).

As with flux, there was a large range in $S_{\mathrm{P}}$ (7.3-23.9 \%o) among the 16 chamber samples (Fig. 4). Time after fertilization appeared to be an important contributor to this variation. It had a significant influence on $S_{\mathrm{P}}(\mathrm{p}<0.001)$ and accounted for $80 \%$ of the variance associated with $S_{\mathrm{P}}$. The high $S_{\mathrm{P}}$ on the first sampling date, July 8, 2019 was significantly different from all subsequent sampling dates $(\mathrm{p}<0.020)$ and the average $S_{\mathrm{P}}$ for that date was $1 \%$ higher than that of the global average for the atmosphere. That coupled with high flux suggests that $\mathrm{N}_{2} \mathrm{O}$ produced by nitrification/fungal denitrification overprinted atmospheric $\mathrm{N}_{2} \mathrm{O}$ and was an important, if not the dominant, contributor to $\mathrm{N}_{2} \mathrm{O}$ emissions. On subsequent sampling dates, $S_{\mathrm{P}}$ values were several per mil lower than that of the atmosphere suggesting that the importance of denitrification to $\mathrm{N}_{2} \mathrm{O}$ production increased later in the season.

The rapid conversion of ammonium to nitrate via nitrification occurs in most agricultural soils and may be particularly important if ammonium-based fertilizers exceed the needs of crops (Norton and Ouyang 2019). During nitrification, $\mathrm{N}_{2} \mathrm{O}$ is produced as a byproduct of nitrification via hydroxylamine oxidation and nitrite reduction (Sutka et al. 2006; Wrage et al. 2001; Wrage-Mönnig et al. 2018). Fungal denitrifiers produce $\mathrm{N}_{2} \mathrm{O}$ with a $S_{\mathrm{P}}$ similar to that of nitrification. These microbes produce $\mathrm{N}_{2} \mathrm{O}$ during the dissimilatory reduction of nitrite and nitrate under low oxygen conditions (Shoun et al. 2012). To place the role of fungal denitrification in context, in situ studies using inhibitors suggest that $\mathrm{N}_{2} \mathrm{O}$ producing activity of 


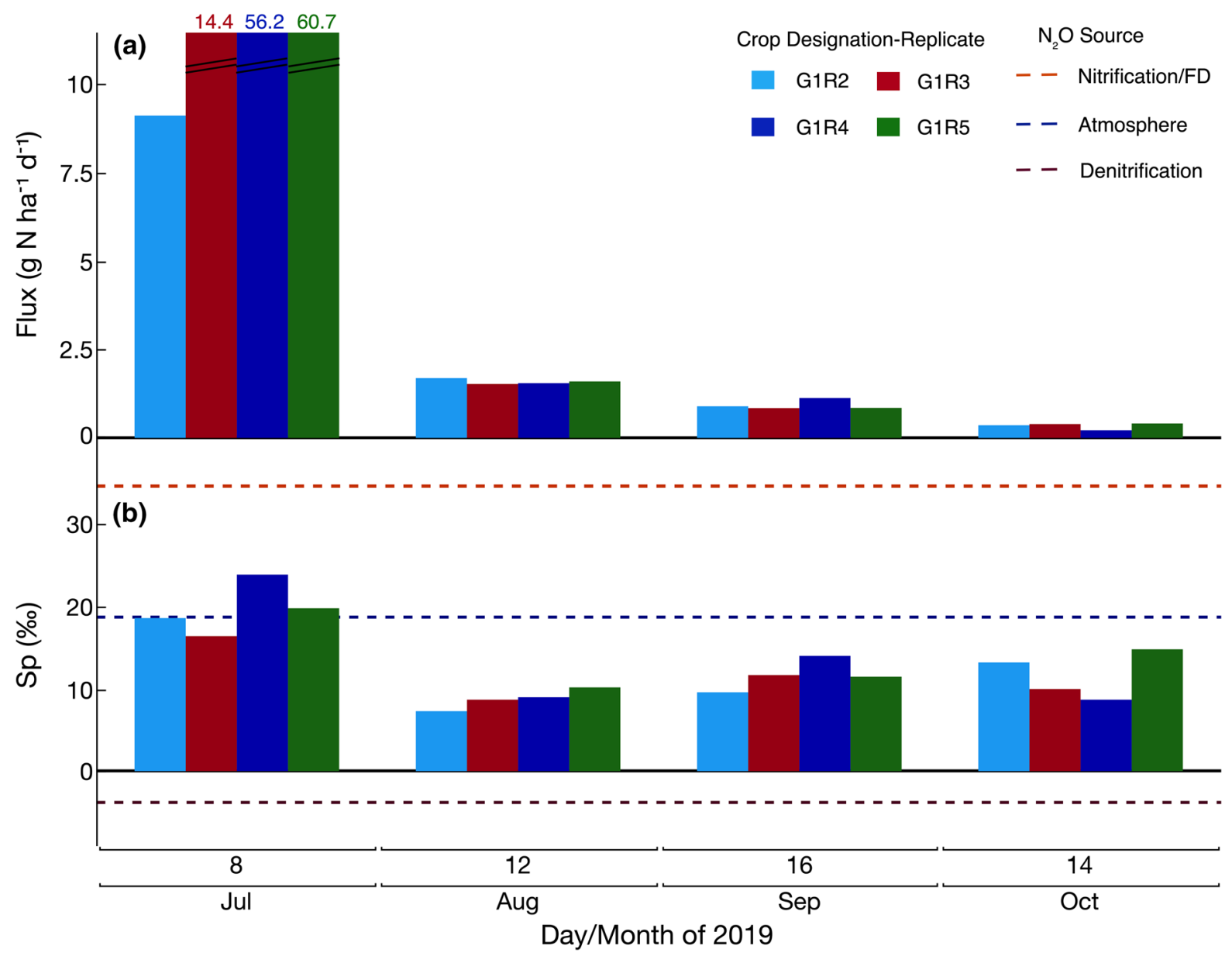

Fig. 4 Flux and Site Preference $\left(S_{\mathrm{P}}\right)$ of $\mathrm{N}_{2} \mathrm{O}$ in samples of headspace from flux chamber placed in four corn (Zea mays) plots associated with the fertilization experiment located within Kellogg Biological Station Biofuel Cropping System Experiment (KBS BCSE). Crop designation G1 was given to corn crops while replicate (R2, R3, R4, and R5) represents separate

fungal and bacterial denitrifiers are comparable (Mothapo et al. 2015). However, it has been long known that inhibitors are inefficient and, thus, conclusions based on inhibitor approaches are incomplete (Oremland and Capone 1988). While we can't assess the relative importance of bacterial nitrification and fungal denitrification, it is fair to say that assessing their relative importance to $\mathrm{N}_{2} \mathrm{O}$ production in situ is important and will require additional study.

\section{Agricultural fertilization experiment: switchgrass}

Extending our agricultural interests, we investigated the perennial biofuel crop switchgrass and asked if experimental plots. Locations of chambers within plots are in Fig. 1. The dashed lines represent the average $S_{\mathrm{P}}$ value of nitrification/fungal denitrification (Nitrification/FD), denitrification, and global average for the atmosphere, $34.8 \%$, $-3.9 \%$ o and $18.7 \%$ respectively (Lewicka-Szczebak et al. 2017). Fertilization occurred on June 5, 2019. (Color figure online)

fertilization changes the $\mathrm{N}_{2} \mathrm{O}$ flux and source relative to non-fertilized switchgrass. The experiment consisted of 20 samples from fertilized and 18 samples from unfertilized sub-plots of the main BSCE plots. Both treatments showed a wide range in $\mathrm{N}_{2} \mathrm{O}$ flux of 0.1-8.5 $\mathrm{g} \mathrm{N}_{2} \mathrm{O}-\mathrm{N} \mathrm{ha}^{-1} \mathrm{~d}^{-1}$ and 0.1-5.2 $\mathrm{g} \mathrm{N}_{2} \mathrm{O}-\mathrm{N} \mathrm{ha}^{-1}$ $\mathrm{d}^{-1}$ in fertilized and unfertilized switchgrass respectively (Fig. 5). The effects of fertilizer treatment, sampling date and the interaction between treatment and sampling date were not significant (model $\mathrm{p}=0.081$ ). Thus, we statistically evaluated the two treatments separately. For fertilized switchgrass, the effect of sampling date on flux was significant ( $p=0.035$ ) and accounted for $48 \%$ of the variance. 


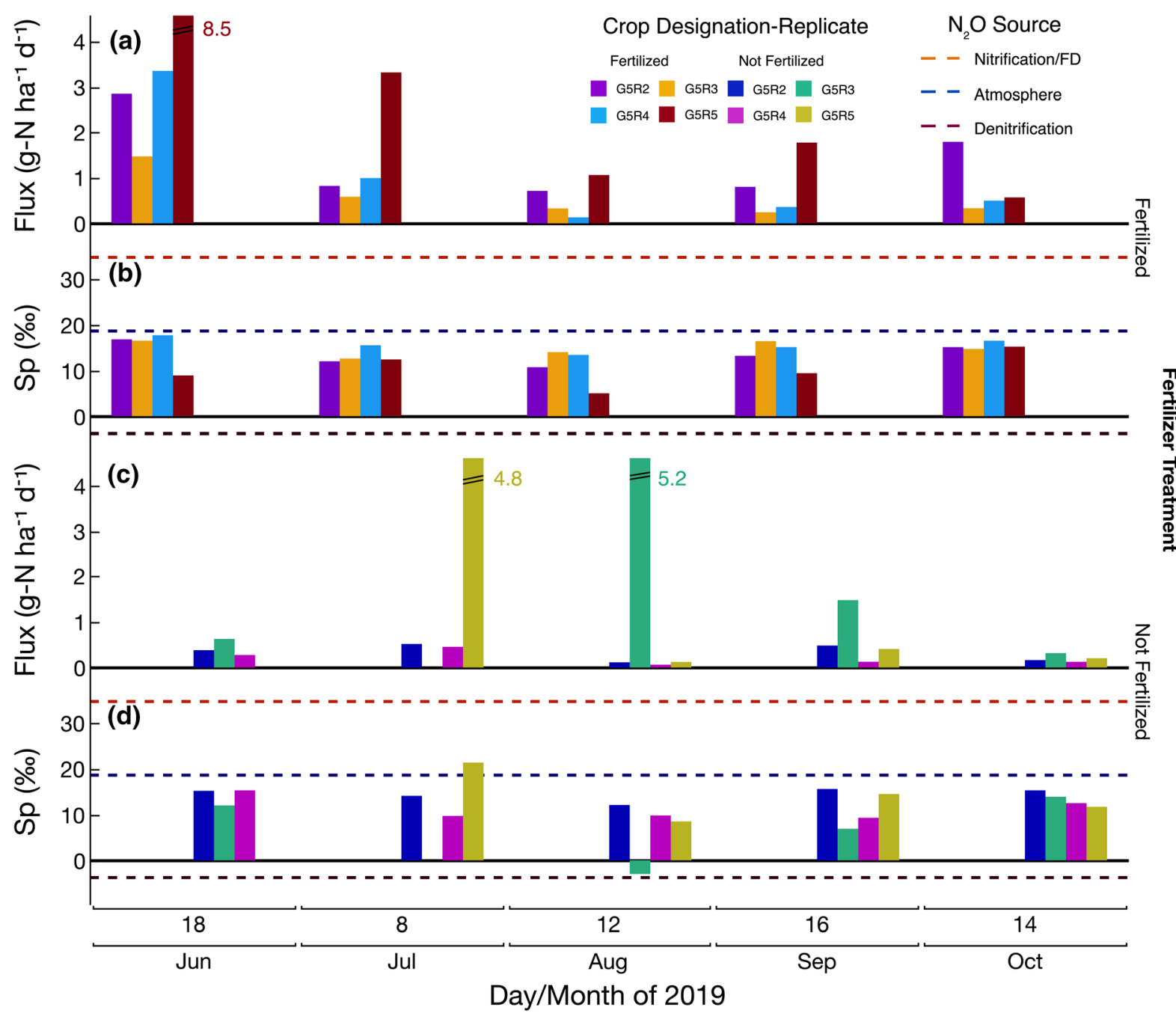

Fig. 5 Flux and Site Preference $\left(S_{\mathrm{P}}\right)$ of $\mathrm{N}_{2} \mathrm{O}$ in samples of headspace of flux chambers in switchgrass (Panicum virgatum) plots associated with the agricultural fertilization experiment located within the Kellogg Biological Station Biofuel Cropping System Experiment (KBS BCSE). Data are from flux chambers in a) fertilized switchgrass and b) unfertilized switchgrass. Crop designation G5 was given to switchgrass while replicate (R2, R3, R4, and R5) represents separate experimental plots. Location of chambers within plots are in Fig. 1. The dashed

Paired comparisons identified a significant difference between June 18 and August 12 of 2019 ( $p=0.044$ ). While it was not a specific objective of this study, we also note that average flux in fertilized switchgrass (1.5 $\mathrm{g} \mathrm{N}_{2} \mathrm{O}-\mathrm{N} \mathrm{ha}{ }^{-1} \mathrm{~d}^{-1}$ ) was much lower than that in corn $\left(9.5 \mathrm{~g} \mathrm{~N}_{2} \mathrm{O}-\mathrm{N} \mathrm{ha} \mathrm{h}^{-1} \mathrm{~d}^{-1}\right)$. In unfertilized switchgrass, sampling date was not a significant predictor of flux $(p=0.618)$. This is likely related to large variation in flux among sampling dates and among lines represent the average $S_{\mathrm{P}}$ value of nitrification/fungal denitrification (Nitrification/FD), denitrification, and global average for the atmosphere, $34.8 \%$, - $3.9 \%$ and $18.7 \%$ respectively (Lewicka-Szczebak et al. 2017). Bars are centered over the date the order fertilized G5R2 to fertilized G5R5 (purple, gold, light blue, brown), unfertilized G5R2 to unfertilized G5R5 (dark blue, bright green, magenta, gold green). Fertilization occurred on May 16, 2019. (Color figure online)

chambers on a specific sampling date (Fig. 5). The highest fluxes occurring in one chamber in July 2019 and another chamber in August 2019.

Both treatments showed a wide range in $S_{\mathrm{P}}$ : 5.0-17.7 \%o in fertilized and -3.0 to $21.3 \%$ in unfertilized switchgrass (Fig. 5). As with flux, the model for $S_{\mathrm{P}}$ with fertilizer treatment, sampling date and the interaction between fertilizer treatment and sampling date was not significant $(p=0.118)$. 
However, the model without the interaction term was significant $(p=0.029)$ with a significant effect of sampling date $(p=0.027)$ but not fertilizer treatment $(\mathrm{p}=0.232)$. Pairwise comparisons show that this was an effect of August 2019 being different from June $2019(\mathrm{p}=0.042)$ and October $2019(\mathrm{p}=0.040)$. Flux chambers from August 2019 exhibited low $S_{\mathrm{P}}$ values relative to October, particularly in non-fertilized subplots. Given that fertilizer treatment was not significant, we statistically evaluated the effect of time after fertilization (sampling date) on fertilized and unfertilized switchgrass separately. For both fertilized and unfertilized switchgrass time after fertilization (sampling date) was not significant $(\mathrm{p}=0.270, \mathrm{p}=0.176$, respectively).

High $\mathrm{N}_{2} \mathrm{O}$ fluxes in perennial biofuel crops soon after fertilization and elevated emissions in annuals relative to perennials has been previously reported (Oates et al. 2015; Smith 2017). In switchgrass, the highest flux was observed in June 18, 2019 in fertilized chambers. As we've mentioned earlier, there are numerous reasons why flux varies within and among crops and many of these relate to variation in microbial processes that influence $\mathrm{N}_{2} \mathrm{O}$ production (Hénault et al. 2012; Smith 2017). The average $S_{\mathrm{P}}$ for fertilized switchgrass on June 18, 2019 was $3.7 \%$ lower than that of the global average for the atmosphere indicating an increase in $\mathrm{N}_{2} \mathrm{O}$ production from bacterial denitrification.

Variability in flux and $S_{\mathrm{P}}$ among sampling dates is a salient feature of this experiment. While low $S_{\mathrm{P}}$ values relative to that of the global average for the atmosphere were common in switchgrass, high variability among chambers and sampling dates suggests variation in the origin of $\mathrm{N}_{2} \mathrm{O}$. On August 12, 2019 in nonfertilized switchgrass there was a high flux and low $S_{\mathrm{P}}$ value in chamber G5R3 $\left(5.2 \mathrm{~g} \mathrm{~N}_{2} \mathrm{O}-\mathrm{N} \mathrm{ha}^{-1} \mathrm{~d}^{-1},-3.0\right.$ \%o) and a low flux and higher $S_{\mathrm{P}}$ in chamber G5R2 $\left(0.1 \mathrm{~g} \mathrm{~N}_{2} \mathrm{O}-\mathrm{N} \mathrm{ha}^{-1} \mathrm{~d}^{-1}, 12.1 \%\right.$ ). The low $S_{\mathrm{P}}$ of G5R3 suggests that bacterial denitrification had a much stronger influence in this chamber than in G5R2. Other chambers, for example G5R5 in unfertilized switchgrass in July 2019 (flux $=4.8 \mathrm{~g} \mathrm{~N}_{2} \mathrm{O}-\mathrm{N} \mathrm{ha}^{-1} \mathrm{~d}^{-1} \mathrm{~N}_{2} \mathrm{O}$, $S_{\mathrm{P}}=21.3 \%$ ), are good indicators that nitrification was an important source of $\mathrm{N}_{2} \mathrm{O}$. While any two flux chambers could be as much as $175 \mathrm{~m}$ apart, the observed variation in flux and $S_{\mathrm{P}}$ emphasizes that large scale features (e.g. meteorological, topographic) are not the only controls on flux and $S_{\mathrm{P}}$ and emphasize the complexity of identifying and interpreting the origins of $\mathrm{N}_{2} \mathrm{O}$ in field settings.

\section{Site Preference of Atmospheric $\mathrm{N}_{2} \mathrm{O}$}

The $S_{\mathrm{P}}$ of atmospheric $\mathrm{N}_{2} \mathrm{O}$ from both the grassland tilling and agricultural fertilizer experiments was highly variable with a range of -5.1 to $32 \%$ for 57 samples in the grassland and 2.1-12.5\% for 4 samples from the fertilizer experiment (Fig. 6, Table S1, S2). The observation that the samples from both experiments differed by at least $2 \%$ from that of the average for the global suggests that microbial processes influence near surface ( $2 \mathrm{~m}$ above ground) atmospheric $\mathrm{N}_{2} \mathrm{O}$. The wide range in atmospheric $\mathrm{N}_{2} \mathrm{O}$ concentration (e.g. 314-367 ppbv in the grassland) supports this conclusion (Table S1, S2).

The disparity in $S_{\mathrm{P}}$ between the global atmosphere and our atmospheric data was not a function of localized sampling. The disparity occurred at 2 study sites separated by ca. $100 \mathrm{~km}$ and 2 sites within the grassland separated by $100 \mathrm{~m}$ apart.

Our results suggest that soil microbial processes influence the atmosphere at $2 \mathrm{~m}$ above the surface. The extremely low and high values $(-5.1 \%$ and 32 $\%$ ) are similar to those of the endmembers for nitrification/fungal denitrification and bacterial dentrification and suggest that in these cases the majority, if not all, of the $\mathrm{N}_{2} \mathrm{O}$ measured at $2 \mathrm{~m}$ derives from the soil. We wondered if soil derived $\mathrm{N}_{2} \mathrm{O}$ was a significant component of the atmosphere above $2 \mathrm{~m}$. Subsequent to the experiment conducted for this paper, several samples of atmosphere were taken on October 24, 2019 simultaneously at 2 and 4 m over the course of several hours (Fig. S1). The concentration of $\mathrm{N}_{2} \mathrm{O}$ atmosphere (315-316 ppbv) was below the average for the global atmosphere (330 ppbv) suggesting the influence of microbial consumption of $\mathrm{N}_{2} \mathrm{O}$. In most cases, $S_{\mathrm{P}}$ values at the two heights were within $2 \%$ of each other with values as low as $12.6 \%$ at $2 \mathrm{~m}$. This indicates that soil derived $\mathrm{N}_{2} \mathrm{O}$ is influential at $4 \mathrm{~m}$, further calling into question the use of the global average value for atmospheric $S_{\mathrm{P}}$ in near surface isotope modelling approaches.

Future studies aimed at estimating the $S_{\mathrm{P}}$ of soil derived $\mathrm{N}_{2} \mathrm{O}$ from flux chambers will need to determine the $S_{\mathrm{P}}$ of the atmosphere within the chamber prior to closing. We also recommend the use of large volume chambers that minimize the contribution of 


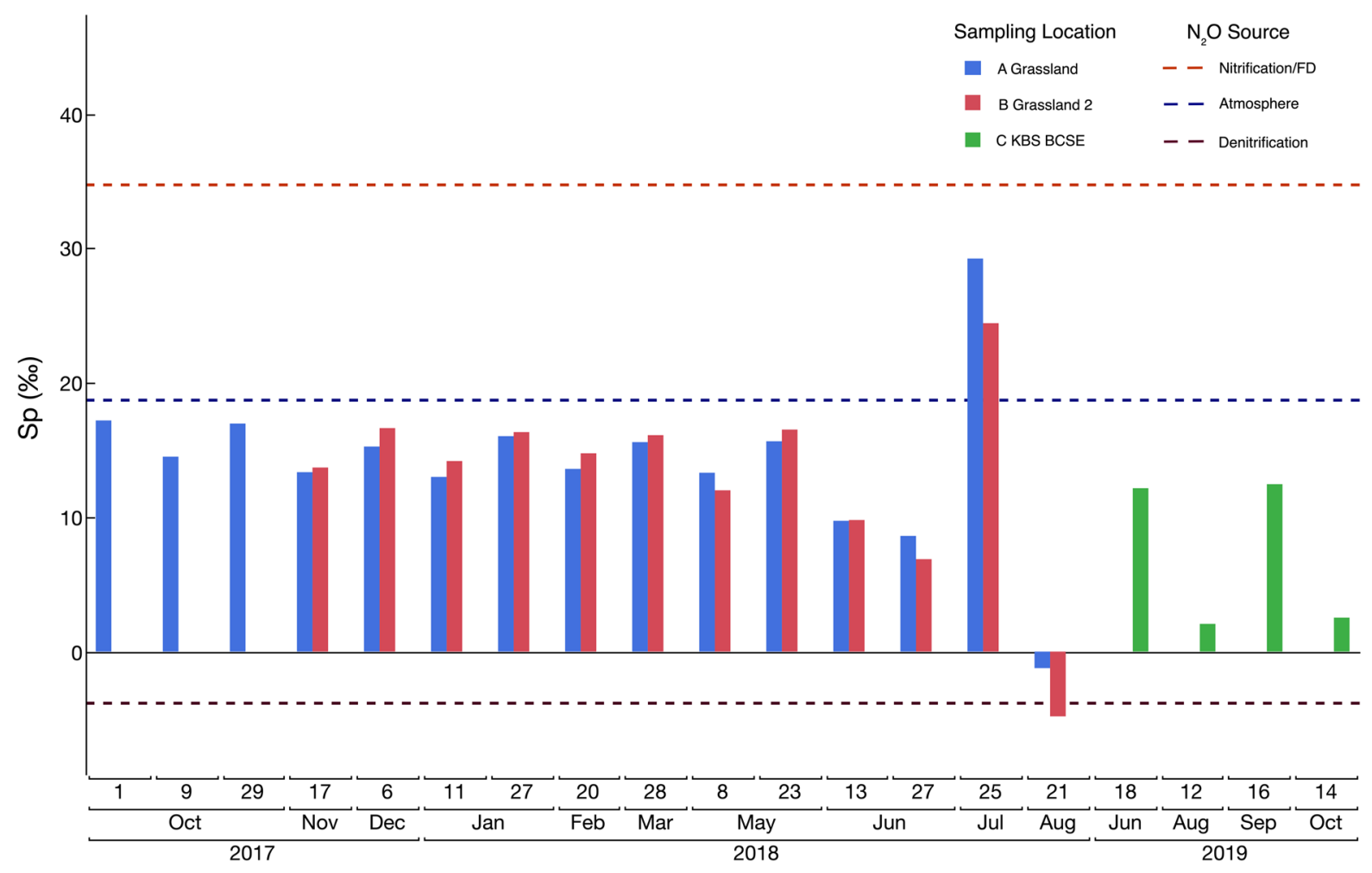

Fig. 6 Flux and Site Preference $\left(S_{\mathrm{P}}\right)$ of $\mathrm{N}_{2} \mathrm{O}$ in samples of atmosphere taken in two locations in the grassland (blue and red bars) and one location in the agricultural fertilization experiment (green bars) located in Okemos, MI and Kellogg Biological Station, respectively. Samples of atmosphere were taken at $2 \mathrm{~m}$ above ground. Each bar represents a single or

atmosphere when it ingresses to the chamber upon sampling. Additional experiments are needed to delineate the maximum height to which microbial processes influence the atmosphere and to identify the factors that control the origins of near surface atmospheric $\mathrm{N}_{2} \mathrm{O}$.

\section{Conclusions}

Understanding the relative importance of soil microbial processes on atmospheric $\mathrm{N}_{2} \mathrm{O}$ concentrations is the necessary first step in mitigating $\mathrm{N}_{2} \mathrm{O}$ emissions. The observation of high $S_{\mathrm{P}}$ in some of our chamber and atmosphere samples emphasizes that one should not assume that bacterial denitrification is the predominant source of $\mathrm{N}_{2} \mathrm{O}$ in all grasslands or agricultural systems. Even values $3 \%$ below that of the global atmosphere could derive from equal amounts of average of two or three samples. Dashed lines represent the average $S_{\mathrm{P}}$ value of nitrification/fungal denitrification (Nitrification/FD), denitrification, and global average for the atmosphere, $34.8 \%$, $-3.9 \%$ and $18.7 \%$ respectively (LewickaSzczebak et al. 2017). (Color figure online)

nitrification/fungal denitrification and denitrification, depending on the magnitude of $\mathrm{N}_{2} \mathrm{O}$ flux. Variability in flux and $S_{\mathrm{P}}$ among sampling dates was a salient feature of each of our experiments. Given this variation in $S_{\mathrm{P}}$, the next challenges will be to capture, constrain and interpret spatial and temporal $S_{\mathrm{P}}$ variability; identify the factors controlling this variation within different ecosystems and determine the degree to which individual microbial sources of $\mathrm{N}_{2} \mathrm{O}$ influence the atmosphere. Flux gradient methods coupled with spectroscopic approaches (e.g. Ibraim et al. 2019) are amenable to this task but include the challenge of careful accurate calibration. Given the increasing pressure to expand agriculture to meet the needs of an ever-growing global population solving these future challenges is an important, if not essential, step in reducing $\mathrm{N}_{2} \mathrm{O}$ emissions. 
Acknowledgements This manuscript is based upon work supported by a U.S. Department of Energy, Office of Science, Office of Biological and Environmental Research Award (DESC0018409) to the Great Lakes Bioenergy Research Center. We thank Doug Baer for assistance in providing instrumentation, Manish Gupta and Feng Dong for their technical expertise and Jenie Gil Lugo, Phillip G. Robertson and Kevin Kahmark for consulting on the experimental design and placement of flux chambers at KBS BCSE. We also appreciate Jenie Gil Lugo's assistance with the collection of samples from KBS BCSE flux chambers in June 2019 and independent sampling in July 2019. We thank Stacey Vanderwulp who facilitated chamber closing on numerous occasions at KBS BCSE.

Author contributions PHO, SD and NEO collected samples. All authors analyzed data. PHO was the main author whose writing benefited from numerous in-depth technical discussions with NEO. All authors discussed, reviewed and edited the manuscript.

Funding This manuscript is based upon work supported by a U.S. Department of Energy, Office of Science, Office of Biological and Environmental Research Award (DESC0018409) to the Great Lakes Bioenergy Research Center.

Data availability All data are available in the electronic supplementary documents.

Code availability There is no custom code or software application.

\section{Compliance with ethical standards}

Conflict of interest The authors declare that they have no conflicts of interest.

Informed consent All authors have consented to participate and publish this work.

Open Access This article is licensed under a Creative Commons Attribution 4.0 International License, which permits use, sharing, adaptation, distribution and reproduction in any medium or format, as long as you give appropriate credit to the original author(s) and the source, provide a link to the Creative Commons licence, and indicate if changes were made. The images or other third party material in this article are included in the article's Creative Commons licence, unless indicated otherwise in a credit line to the material. If material is not included in the article's Creative Commons licence and your intended use is not permitted by statutory regulation or exceeds the permitted use, you will need to obtain permission directly from the copyright holder. To view a copy of this licence, visit http://creativecommons.org/licenses/by/4.0/.

\section{References}

Aneja VP, Schlesinger WH, Li Q et al (2019) Characterization of atmospheric nitrous oxide emissions from global agricultural soils. SN Appl Sci 1:1-11. https://doi.org/10.1007/ s42452-019-1688-5

Baggs EM (2008) A review of stable isotope techniques for $\mathrm{N}_{2} \mathrm{O}$ source partitioning in soils: recent progress, remaining challenges and future considerations. Rapid Commun Mass Spectrom 22:1664-1672. https://doi.org/10.1002/ rcm.3456

Bol R, Toyoda S, Yamulki S et al (2003) Dual isotope and isotopomer ratios of $\mathrm{N}_{2} \mathrm{O}$ emitted from a temperate grassland soil after fertilizer application. Rapid Commun Mass Spectrom 17:2550-2556. https://doi.org/10.1002/rcm. 1223

Congreves KA, Phan T, Farrell RE (2019) A new look at an old concept: Using ${ }^{15} \mathrm{~N}_{2} \mathrm{O}$ isotopomers to understand the relationship between soil moisture and $\mathrm{N}_{2} \mathrm{O}$ production pathways. Soil. https://doi.org/10.5194/soil-5-265-2019

Decock C, Six J (2013) On the potential of $\delta^{18} \mathrm{O}$ and $\delta^{15} \mathrm{~N}$ to assess $\mathrm{N}_{2} \mathrm{O}$ reduction to $\mathrm{N}_{2}$ in soil. Eur $\mathrm{J}$ Soil Sci 64:610-620. https://doi.org/10.1111/ejss.12068

Duncan DS, Oates LG, Gelfand I et al (2019) Environmental factors function as constraints on soil nitrous oxide fluxes in bioenergy feedstock cropping systems. GCB Bioenergy 11:416-426. https://doi.org/10.1111/gcbb.12572

Flesch TK, Baron VS, Wilson JD et al (2018) Micrometeorological measurements reveal large nitrous oxide losses during spring thaw in Alberta. Atmosphere (Basel) 9:1-13. https://doi.org/10.3390/atmos9040128

Gelfand I, Robertson GP (2015) Mitigation of greenhouse gases in agricultural ecosystems. In: Hamilton SK, Doll JE, Robertson GP (eds) The Ecology of Agricultural Landscapes: Long-Term Research on the Path to Sustainability, vol 3. Oxford University Press, New York, pp 310-339

Grandy AS, Robertson GP (2006a) Initial cultivation of a temperate-region soil immediately accelerates aggregate turnover and $\mathrm{CO}_{2}$ and $\mathrm{N}_{2} \mathrm{O}$ fluxes. Glob Chang Biol 12:1507-1520. https://doi.org/10.1111/j.1365-2486.2006. 01166.x

Grandy AS, Robertson GP (2006b) Aggregation and Organic Matter Protection Following Tillage of a Previously Uncultivated Soil. Soil Sci Soc Am J 70:1398-1406. https://doi.org/10.2136/sssaj2005.0313

Grandy AS, Robertson GP (2007) Land-use intensity effects on soil organic carbon accumulation rates and mechanisms. Ecosystems 10:58-73. https://doi.org/10.1007/s10021006-9010-y

Groffman PM, Butterbach-Bahl K, Fulweiler RW et al (2009) Challenges to incorporating spatially and temporally explicit phenomena (hotspots and hot moments) in denitrification models. Biogeochemistry 93:49-77. https://doi. org/10.1007/s10533-008-9277-5

Harris SJ, Liisberg J, Xia L, Wei J, Zeyer K, Yu L, Blunier T (2020) $\mathrm{N}_{2} \mathrm{O}$ isotopocule measurements using laser spectroscopy: analyzer characterization and intercomparison. Atmospheric Measurement Techniques. https://doi.org/10. 5194/amt-13-2797-2020 
Haslun JA, Ostrom NE, Hegg EL, Ostrom PH (2018) Estimation of isotope variation of $\mathrm{N}_{2} \mathrm{O}$ during denitrification by Pseudomonas aureofaciens and Pseudomonas chlororaphis: implications for $\mathrm{N}_{2} \mathrm{O}$ source apportionment. Biogeosciences. https://doi.org/10.5194/bg-15-3873-2018

Hénault C, Grossel A, Mary B et al (2012) Nitrous Oxide Emission by Agricultural Soils: A Review of Spatial and Temporal Variability for Mitigation. Pedosphere 22:426-433. https://doi.org/10.1016/S10020160(12)60029-0

Ibraim E, Wolf B, Harris E et al (2019) Attribution of $\mathrm{N}_{2} \mathrm{O}$ sources in a grassland soil with laser spectroscopy based isotopocule analysis. Biogeosciences. https://doi.org/10. 5194/bg-16-3247-2019

Intergovernmental Panel on Climate Change (2014) Climate Change 2014 Mitigation of Climate Change. Cambridge University Press, Cambridge. https://doi.org/10.1017/ CBO9781107415416

Jinuntuya-Nortman M, Sutka RL, Ostrom PH et al (2008) Isotopologue fractionation during microbial reduction of $\mathrm{N}_{2} \mathrm{O}$ within soil mesocosms as a function of water-filled pore space. Soil Biol Biochem 40:2273-2280. https://doi.org/ 10.1016/j.soilbio.2008.05.016

Kim DG, Vargas R, Bond-Lamberty B, Turetsky MR (2012) Effects of soil rewetting and thawing on soil gas fluxes: A review of current literature and suggestions for future research. Biogeosciences. https://doi.org/10.5194/bg-92459-2012

Kravchenko AN, Guber AK, Quigley MY et al (2018) X-ray computed tomography to predict soil $\mathrm{N}_{2} \mathrm{O}$ production via bacterial denitrification and $\mathrm{N}_{2} \mathrm{O}$ emission in contrasting bioenergy cropping systems. GCB Bioenergy 10:894-909. https://doi.org/10.1111/gcbb.12552

Kravchenko AN, Robertson GP (2015) Statistical Challenges in Analyses of Chamber-Based Soil $\mathrm{CO}_{2}$ and $\mathrm{N}_{2} \mathrm{O}$ Emissions Data. Soil Sci Soc Am J 79:200-211. https://doi.org/10. 2136/sssaj2014.08.0325

Kravchenko AN, Toosi ER, Guber AK et al (2017) Hotspots of soil $\mathrm{N}_{2} \mathrm{O}$ emission enhanced through water absorption by plant residue. Nat Geosci 10:496-500. https://doi.org/10. 1038/ngeo2963

Lewicka-Szczebak D, Augustin J, Giesemann A et al (2017) Quantifying $\mathrm{N}_{2} \mathrm{O}$ reduction to $\mathrm{N}_{2}$ based on $\mathrm{N}_{2} \mathrm{O}$ isotopocules-validation with independent methods (helium incubation and ${ }^{15} \mathrm{~N}$ gas flux method). Biogeosciences. https://doi.org/10.5194/bg-14-711-2017

McGill BM, Hamilton SK, Millar N, Robertson GP (2018) The greenhouse gas cost of agricultural intensification with groundwater irrigation in a Midwest U.S. row cropping system. Glob Chang Biol 24:5948-5960. https://doi.org/ 10.1111/gcb.14472

McSwiney CP, Robertson GP (2005) Nonlinear response of $\mathrm{N}_{2} \mathrm{O}$ flux to incremental fertilizer addition in a continuous maize (Zea mays L.) cropping system. Glob Chang Biol 11:1712-1719. https://doi.org/10.1111/j.1365-2486.2005. 01040.x

Mothapo N, Chen H, Cubeta MA et al (2015) Phylogenetic, taxonomic and functional diversity of fungal denitrifiers and associated $\mathrm{N}_{2} \mathrm{O}$ production efficacy. Soil Biol Biochem 83:160-175. https://doi.org/10.1016/j.soilbio.2015.02.001
Neftel A, Flechard C, Ammann C et al (2007) Experimental assessment of $\mathrm{N}_{2} \mathrm{O}$ background fluxes in grassland systems. Tellus, Ser B Chem Phys Meteorol 59:470-482. https://doi.org/10.1111/j.1600-0889.2007.00273.x

Norton J, Ouyang Y (2019) Controls and Adaptive Management of Nitrification in Agricultural Soils. Front Microbiol 10:1-18. https://doi.org/10.3389/fmicb.2019.01931

Oates LG, Duncan DS, Gelfand I et al (2015) Nitrous oxide emissions during establishment of eight alternative cellulosic bioenergy cropping systems in the North Central United States. GCB Bioenergy 8:539-549. https://doi.org/ 10.1111/gcbb. 12268

Opdyke MR, Ostrom NE, Ostrom PH (2009) Evidence for the predominance of denitrification as a source of $\mathrm{N}_{2} \mathrm{O}$ in temperate agricultural soils based on isotopologue measurements. Global Biogeochem Cycles 23:1-10. https:// doi.org/10.1029/2009GB003523

Oremland RS, Capone DG (1988) Use of "Specific" Inhibitors in Biogeochemistry and Microbial Ecology. In: Marshall $\mathrm{KC}$ (ed) Advances in Microbial Ecology. Springer, Boston, pp 285-383

Ostrom NE, Gandhi H, Coplen TB et al (2018) Preliminary assessment of stable nitrogen and oxygen isotopic composition of USGS51 and USGS52 nitrous oxide reference gases and perspectives on calibration needs. Rapid Commun Mass Spectrom. https://doi.org/10.1002/rcm.8257

Ostrom NE, Ostrom PH (2012) The Isotopomers of Nitrous Oxide: Analytical Considerations and Application to Resolution of Microbial Production Pathways. In: Baskaran M (ed) Handbook of Environmental Isotope Geochemistry. Advances in Isotope Geochemistry, Springer, Heidelberg, pp 453-476

Ostrom NE, Ostrom PH (2017) Mining the isotopic complexity of nitrous oxide: a review of challenges and opportunities. Biogeochemistry 132:359-372. https://doi.org/10.1007/ s10533-017-0301-5

Ostrom NE, Pitt A, Sutka RL, Ostrom PH, Grandy AS, Huizinga KM, Robertson GP (2007) Isotopologue effects during $\mathrm{N}_{2} \mathrm{O}$ reduction in soils and in pure cultures of denitrifiers. J Geophys Res 112:1-12. https://doi.org/10.1029/ 2006JG000287

Park S, Croteau P, Boering KA et al (2012) Trends and seasonal cycles in the isotopic composition of nitrous oxide since 1940. Nat Geosci. https://doi.org/10.1038/ngeo1421

Park S, Pérez T, Boering KA et al (2011) Can $\mathrm{N}_{2} \mathrm{O}$ stable isotopes and isotopomers be useful tools to characterize sources and microbial pathways of $\mathrm{N}_{2} \mathrm{O}$ production and consumption in tropical soils? Global Biogeochem Cycles 25:1-16. https://doi.org/10.1029/2009GB003615

Prather MJ, Hsu J, DeLuca NM, Jackman CH et al (2015) Measuring and modeling the lifetime of nitrous oxide including its variability. J Geophys Res 120:5693-5705. https://doi.org/10.1002/2015JD023267

Prinn RG (2013) Development and application of earth system models. Proc Natl Acad Sci 110:3673-3680. https://doi. org/10.1073/pnas.1107470109

Prinn RG, Weiss RF, Fraser PJ et al (2000) A history of chemically and radiatively important gases in air deduced from ALE/GAGE/AGAGE. J Geophys Res Atmos. https:// doi.org/10.1029/2000JD900141 
Ravishankara A (2009) Findings from the 2006 Ozone Scientific Assessment for the Montreal Protocol. In: Zerefos C, Contopoulos G, Skalkeas G (eds) Twenty Years of Ozone Decline. Springer, Netherlands, pp 387-391

Ruan L, Robertson GP (2017) Reduced Snow Cover Increases Wintertime Nitrous Oxide $\left(\mathrm{N}_{2} \mathrm{O}\right)$ Emissions from an Agricultural Soil in the Upper U.S. Midwest Ecosystems 20:917-927. https://doi.org/10.1007/s10021-016-0077-9

Shcherbak I, Millar N, Robertson GP (2014) Global metaanalysis of the nonlinear response of soil nitrous oxide $\left(\mathrm{N}_{2} \mathrm{O}\right)$ emissions to fertilizer nitrogen. Proc Natl Acad Sci U S A 111:9199-9204. https://doi.org/10.1073/pnas. 1322434111

Shoun H, Fushinobu S, Jiang L et al (2012) Fungal denitrification and nitric oxide reductase cytochrome P450nor. Philos Trans R Soc B Biol Sci 367:1186-1194. https://doi.org/10. 1098/rstb.2011.0335

Smith KA (2017) Changing views of nitrous oxide emissions from agricultural soil: key controlling processes and assessment at different spatial scales. Eur J Soil Sci 68:137-155. https://doi.org/10.1111/ejss.12409

Sutka RL, Adams GC, Ostrom NE, Ostrom PH (2008) Isotopologue fractionation during $\mathrm{N}_{2} \mathrm{O}$ production by fungal denitrification. Rapid Commun Mass Spectrom 22:3989-3996. https://doi.org/10.1002/rcm.3820

Sutka RL, Ostrom NE, Ostrom PH et al (2003) Nitrogen isotopomer site preference of $\mathrm{N}_{2} \mathrm{O}$ produced by Nitrosomonas europaea andMethylococcus capsulatus Bath. Rapid Commun Mass Spectrom 17:738-745. https://doi.org/10. 1002/rcm.968

Sutka RL, Ostrom NE, Ostrom PH et al (2006) Distinguishing nitrous oxide production from nitrification and denitrification on the basis of isotopomer abundances. Appl Environ Microbiol 72:638-644. https://doi.org/10.1128/AEM. 72.1.638-644.2006

Toyoda S, Kuroki N, Yoshida N et al (2013) Decadal time series of tropospheric abundance of $\mathrm{N}_{2} \mathrm{O}$ isotopomers and isotopologues in the Northern Hemisphere obtained by the long-term observation at Hateruma Island, Japan.
J Geophys Res Atmos 118:3369-3381. https://doi.org/10. 1002/jgrd.50221

Toyoda S, Mutobe H, Yamagishi H et al (2005) Fractionation of $\mathrm{N}_{2} \mathrm{O}$ isotopomers during production by denitrifier. Soil Biol Biochem 37:1535-1545. https://doi.org/10.1016/j. soilbio.2005.01.009

Toyoda S, Yoshida N, Koba K (2017) Isotopocule analysis of biologically produced nitrous oxide in various environments. Mass Spectrom Rev 36:135-160. https://doi.org/10. 1002/mas.21459

Ussiri D, Lal R (2013) Global Sources of Nitrous Oxide. In: Ussiri D, Lal R (eds) Soil Emission of Nitrous Oxide and its Mitigation. Springer, Netherlands, pp 131-175

Wang Q, Zhou F, Shang Z et al (2020) Data-driven estimates of global nitrous oxide emissions from croplands. Natl Sci Rev 7:441-452. https://doi.org/10.1093/nsr/nwz087

WMO and GAW: Greenhouse Gas Bulletin, The State of Greenhouse Gases in the Atmosphere Based on Global Observations through 2016, WMO

Wrage N, Velthof G, van Beusichem M, Oenema O (2001) Role of nitrifier denitrification in the production of nitrous oxide. Soil Biol Biochem 33:1723-1732. https://doi.org/10.1016/ S0038-0717(01)00096-7

Wrage-Mönnig N, Horn MA, Well R et al (2018) The role of nitrifier denitrification in the production of nitrous oxide revisited. Soil Biol Biochem 123:A3-A16. https://doi.org/ 10.1016/j.soilbio.2018.03.020

Yoshida N, Toyoda S (2000) Constraining the atmospheric $\mathrm{N}_{2} \mathrm{O}$ budget from intramolecular site preference in $\mathrm{N}_{2} \mathrm{O}$ isotopomers. Nature 405:330-334. https://doi.org/10.1038/ 35012558

Yu L, Harris E, Henne S et al (2019) The isotopic composition of atmospheric nitrous oxide observed at the high-altitude research station Jungfraujoch, Switzerland. Atmos Chem Phys Discuss. https://doi.org/10.5194/acp-2019-829

Publisher's Note Springer Nature remains neutral with regard to jurisdictional claims in published maps and institutional affiliations. 